\title{
Desain Interior SMP Negeri untuk Membentuk Karakter Disiplin Siswa
}

\author{
Rofi'atul Ilmia dan Aria Weny Anggraita \\ Departemen Desain Interior, Fakultas Teknik Sipil dan Perencanaan, Institut Teknologi Sepuluh Nopember (ITS) \\ e-mail: rofiatul.ilmia22@gmail.com
}

\begin{abstract}
Abstrak - Sekolah yang disiplin perlu diciptakan agar anak dapat belajar tidak hanya keterampilan akademik akan tetapi juga melatih siswa untuk mencapai hal-hal non-akademik yang juga sangat penting bagi kehidupan, yaitu taat pada peraturan untuk membentuk kepribadian yang baik. SMP Negeri 2 Deket sebagai salah satu lembaga pendidikan untuk anak usia remaja yang mempunyai misi yaitu terwujudnya strategi pembelajaran yang aktif, kreatif, inovatif, menyenangkan dalam upaya pelestarian fungsi lingkungan; serta terwujudnya sistem penilaian sesuai Standar Nasional. Untuk menunjang misi tersebut, maka diperlukan pengaplikasian desain interior pada sekolah yang disesuaikan dengan pembentukan karakter siswa melalui kedisiplinan akan sangat berpengaruh terhadap perkembangan dan perilaku anak. Hal ini dapat dilalukan dengan cara mendesain interior sekolah yang dapat mengarahkan siswa agar lebih fokus dalam kegiatan dan aktifitas pendukung belajar mengajar, mendesain signage dan tata lay out ruang untuk mengarahkan siswa agar bersikap lebih disiplin di sekolah. Dengan desain interior yang tepat maka dapat memberikan solusi desain dari permasalahan kedisiplinan siswa yang ada di SMP Negeri. Desain yang diterapkan untuk visualiasi konsep yang diinginkan adalah penggunaan beberapa kombinasi warna yang sesuai psikologis anak usia SMP untuk membentuk kedisiplinan siswa seperti kuning, biru, hijau, putih, dan coklat; penggunaan bentuk furnitur, dinding, plafon, dan pola lantai yang mengarahkan siswa lebih fokus dalam belajar serta dapat menunjang kedisiplinan anak usia 12-15 tahun; menerapkan signage dan sirkulasi yang lebih informatif untuk mengarahkan anak selalu berperilaku disiplin dan disesuaikan dengan karakter anak usia SMP.
\end{abstract}

Kata Kunci-Disiplin, Interior, Karakter anak usia 12-15 tahun, Signage, Tata Lay out Ruang.

\section{PENDAHULUAN}

$\mathrm{K}$ EDISPLINAN merupakan bekal bagi anak untuk kehidupan masa depannya. Kedisiplinan pada siswa penting untuk dipersiapkan dan dibina semenjak dini. Untuk itu diperlukan kerjasama antar orang tua dengan sekolah karena adanya faktor-faktor dalam kedisiplinan yang perlu mendapat perhatian bersama. Jenis perilaku disiplin yang menyatu dalam segala aspek kepribadian adalah taqwa, patuh, sadar, rasional, mental, teladan, berani, dan kejujuran [1], 2011). Kedisiplinan tidak terjadi dengan sendirinya, melainkan harus ditumbuhkan dari perbuatan dari para pelaku, maka diperlukan suatu latihan atau pelajaran tertentu agar diperoleh seseorang yang mempunyai kedisiplinan yang baik dan mandiri, sehingga dapat mengatur dan mengendalikan dirinya agar melakukan perbuatan yang secara sosial dapat diterima lingkungannya, dan menghindari apa yang dilarangnya.

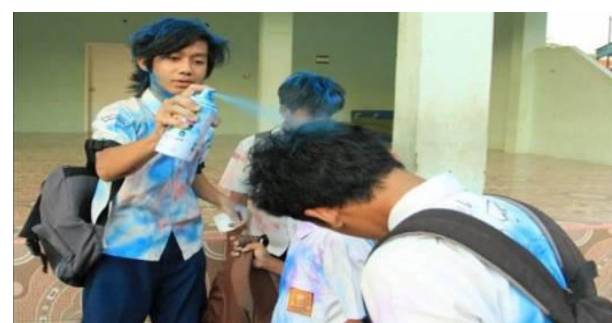

Gambar 1. Salah satu contoh dari perilaku siswa yang kurang disiplin.

Sekolah yang disiplin perlu diciptakan agar anak dapat belajar tidak hanya keterampilan akademik akan tetapi juga melatih siswa untuk mencapai hal-hal non-akademik yang juga sangat penting bagi kehidupan, yaitu taat pada peraturan untuk membentuk kepribadian yang baik [2]. Sekolah juga harus memenuhi kebutuhan seorang anak yang meliputi Lingkungan yang aman dan nyaman, perhatian dari guru dan teman, membantu meningkatkan prestasi, menghormati keberadaan siswa, memberikan kegiatan yang menyenangkan salah satunya melalui kegiatan belajar kelompok, memberikan kesempatan untuk menunjukkan pengetahuan dan keterampilannya. Apabila kebutuhan tersebut tidak terpenuhi maka terjadilah berbagai penyimpangan perilaku atau masalah disiplin. Masalah disiplin di kelas atau sekolah antara lain : makan di dalam kelas, membuat suara gaduh, berbicara saat kegiatan belajar berlangsung, kurang tepat waktu, mengganggu siswa lain, tidak rapi, tidak memperhatikan pelajaran di kelas, dan bertindak kurang baik.

SMP Negeri sebagai salah satu lembaga pendidikan untuk anak usia remaja yang mempunyai misi yaitu terwujudnya strategi pembelajaran yang aktif, kreatif, inovatif, menyenangkan dalam upaya pelestarian fungsi lingkungan; terwujudnya lulusan yang berkompetensi baik secara akademis maupun non akademis serta pendidik dan tenaga kependidikan yang unggul dan berakhlaqul karimah; terwujudnya sarana dan prasarana pendidikan yang memadai, ramah lingkungan dalam upaya mencegah terjadinya pencemaran dan kerusakan lingkungan; serta terwujudnya sistem penilaian sesuai Standar Nasional.

Berdasarkan latar belakang yang telah dijelaskan, untuk meningkatkan prestasi siswa dan kualitas sekolah yang berada di tengah mobilitas kehidupan masyarakat sekarang, maka diperlukan suatu desain interior yang menarik dan dapat memberikan citra baru sesuai visi misi sekolah, coorporate identity, segmentasi sekolah, dan keadaan lingkungan sekolah. Konsep yang akan dipakai pada desain interior SMP Negeri 2 Deket adalah sekolah sebagai sarana pembentukan sikap disiplin pada siswa. 


\section{A. Rumusan Masalah}

1. Bagaimana mendesain interior sekolah untuk mengarahkan siswa agar lebih fokus dalam kegiatan dan aktifitas pendukung belajar mengajar.

2. Bagaimana mendesain signage dan tata lay out antar ruang untuk mengarahkan siswa agar bersikap lebih disiplin di sekolah.

\section{B. Tujuan}

1. Mendesain interior sekolah untuk mengarahkan siswa agar lebih fokus dalam kegiatan dan aktifitas pendukung belajar mengajar.

2. Mendesain signage dan tata lay out antar ruang untuk mengarahkan siswa agar bersikap lebih disiplin di sekolah.

\section{Manfaat}

1. Dapat memberikan solusi desain dari permasalahan kedisiplinan siswa yang ada di SMP Negeri.

2. Siswa di SMP Negeri dapat berkembang secara visual dalam hal kedisplinan dalam belajar dari desain interior yang telah dirancang pada sekolah.

\section{METODE PENELITIAN}

\section{A. Metode Pengumpulan Data}

Pengumpulan data berupa observasi dilakukan di SMP Negeri 2 Deket yang bertujuan mengetahui kondisi mengenai eksisting objek desain, khususnya pada interiornya dan area disekitarnya. Data tersebut meliputi kondisi ruang, kondisi eksisting, fasilitas sekolah, dan data sekolah (logo, visi misi, jumlah siswa, jumlah guru, jumlah karyawan). Yang akan digunakan sebagai dasar dalam mendesain.

\section{B. Metode Analisa Data}

Tahapan ini merupakan analisa data yang diperoleh dari SMP Negeri 2 Deket. Dari hasil analisa ini kemudian menghasilkan alternatif-alternatif desain, yang selanjutnya disimpulkan menjadi desain akhir.

\section{Metode Desain}

Alur metode desain dapat dilihat pada Gambar 2.

\section{KONSEP DESAIN}

\section{A. Konsep Makro}

Perlunya sebuah sekolah sebagai tempat mencari ilmu yang dapat mengarahkan siswa untuk selalu bersikap disiplin agar siswa SMP ini dapat memberikan efek yang positif bagi lingkungan sekitarnya. Untuk itu diolah sebuah konsep desain yakni konsep sekolah sebagai sarana pendidikan untuk membentuk karakter siswa disiplin. Desain yang diterapkan untuk visualiasi konsep yang diinginkan sebagai berikut:

1. Penggunaan beberapa kombinasi warna yang sesuai psikologis anak usia SMP untuk membentuk kedisiplinan siswa seperti kuning, biru, hijau, putih, dan coklat.

2. Penggunaan bentuk furnitur, dinding, plafon, dan pola lantai yang mengarahkan siswa lebih fokus dalam belajar serta dapat menunjang kedisiplinan anak usia 12-15 tahun.

3. Menerapkan signage dan sirkulasi yang lebih informatif untuk mengarahkan anak selalu berperilaku disiplin dan disesuaikan dengan karakter anak usia SMP.

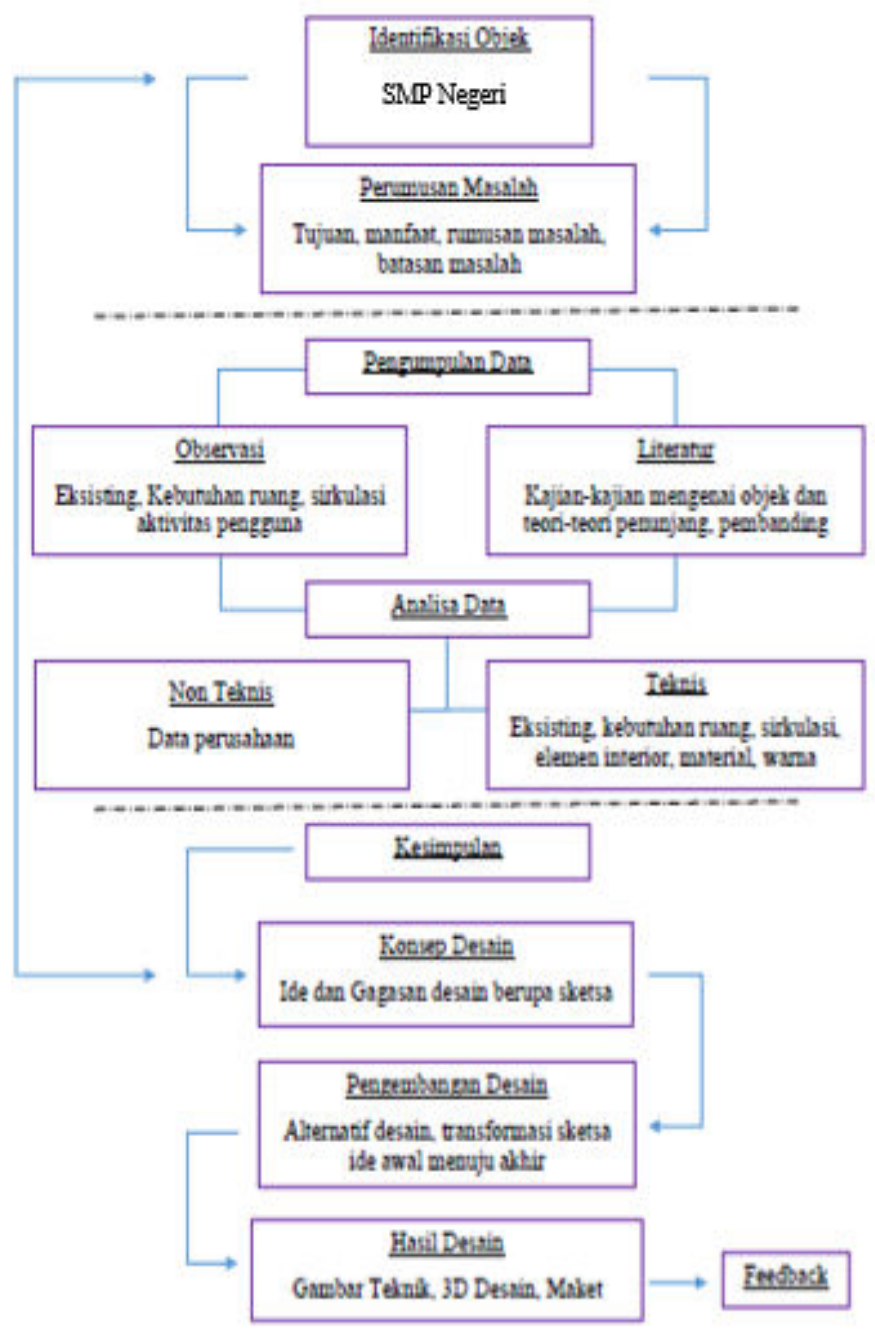

Gambar 2. Alur Metode Desain

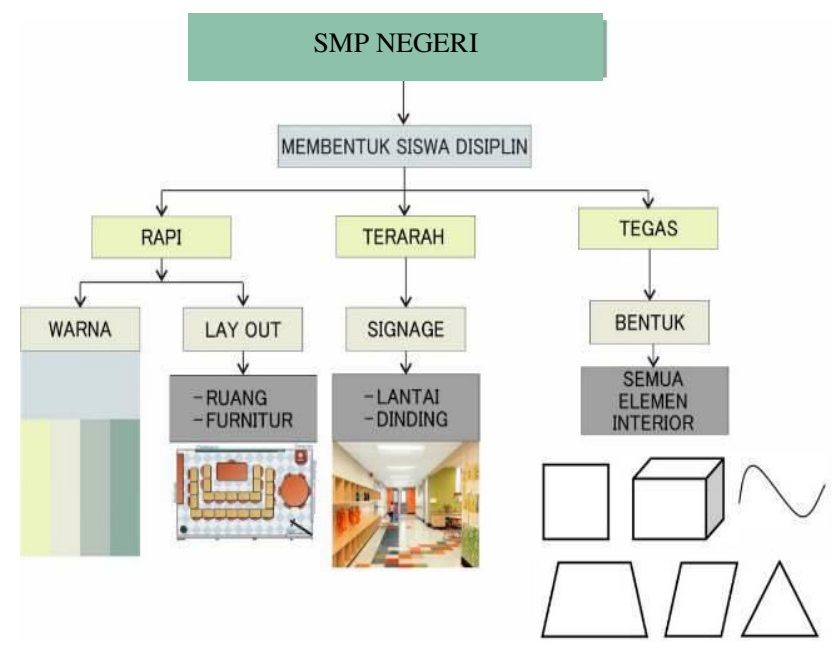

Gambar 3. Rancangan Konsep Desain. 
Gambar 4. Macam- macam warna yang diterapkan dalam desain keseluruhan interior sekolah.

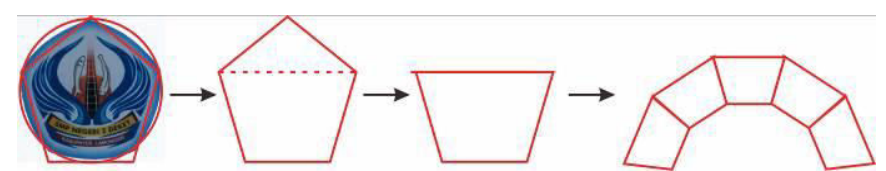

Gambar 5. Contoh lay out furnitur pada ruang kelas yang merupakan aplikasi dari bentuk yang diterapkan dan berasal dari transformasi logo dari SMP Negeri X.

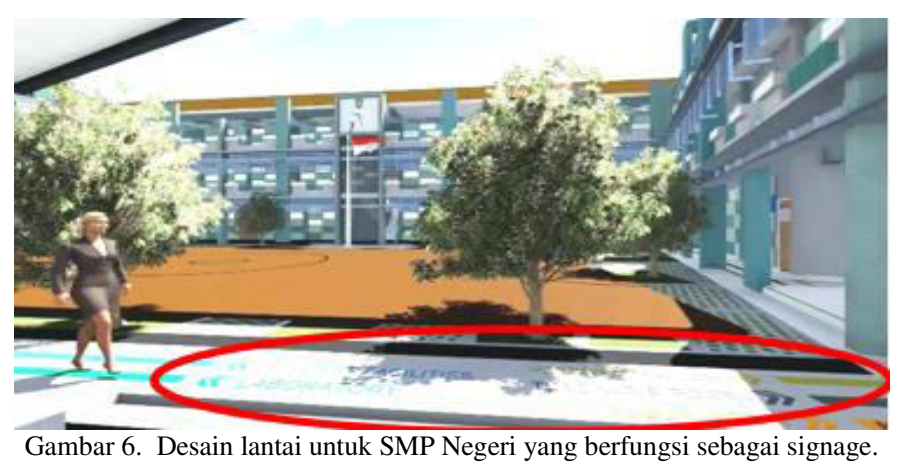

\section{B. Konsep Mikro}

Pengaplikasian konsep pada SMP NEGERI 2 DEKET sebagai objek desain dapat dilihat pada Tabel 1.

\section{1) Konsep Warna}

Dari sisi psikologi, warna mempunyai pengaruh kuat terhadap suasana hati dan emosi manusia, membuat suasana panas atau dingin, provokatif atau simpati, menggairahkan atau menenangkan. Sebagai contoh, ruang yang diberi warna putih atau warna-warna lembut lainnya dapat memberikan kesan bahwa ruang tersebut lebih besar dari dimensi yang sebenarnya. Hal sebaliknya akan terjadi jika ruang menggunakan warna-warna gelap. Untuk mendapatkan sensasi hangat yang sama, ruang yang diberi warna-warna dingin memerlukan pengaturan suhu yang lebih rendah dibandingkan dengan ruang yang diberikan warna-warna hangat [3].

Sesuai dengan masalah kedisiplinan di SMP Negeri, maka dibutuhkan sebuah ketenangan dan kenetralan dalam pembentukan karakter pengguna sekolah terutama siswa [4]. Ketenangan dan kenetralan tersebut dapat dibentuk melalui warna yang sesuai dengan psikologis pengguna (siswa, guru, kepala sekolah, dan karyawan sekolah). Dibutuhkan warnawarna yang dapat meredam emosi pada usia remaja. Gambar dibawah ini merupakan warna yang akan diterapkan dalam desain sekolah (Gambar 4).

\section{2) Konsep Bentuk}

Dalam masalah kedisiplinan di SMP Negeri, maka bentuk yang sesuai dengan psikologis siswa untuk meningkatkan mood belajar dan dapat mengatasi masalah

kurang disiplin pada siswa adalah bentuk dinamis dan teratur. Karena menurut hasil observasi, SMP Negeri ini melakukan

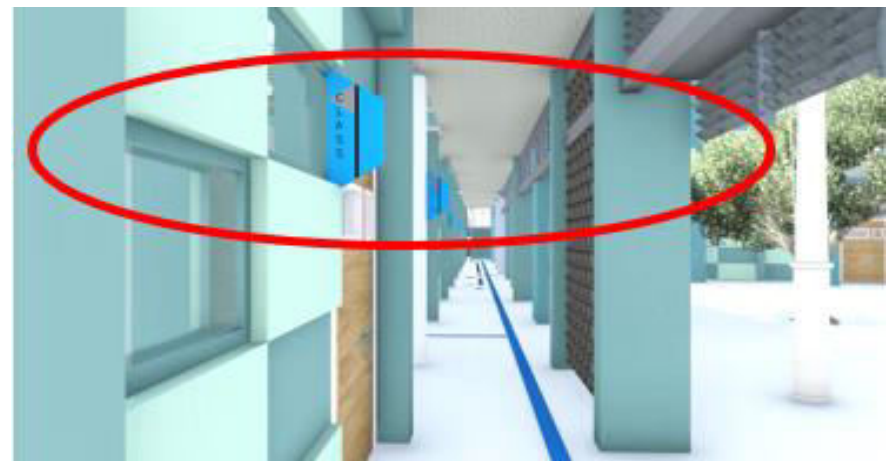

Gambar 7. Desain dinding untuk SMP Negeri yang berfungsi sebagai signage untuk mengarahkan siswa.

Tabel 1

Tabel Aplikasi Konsep Desain pada Rancangan SMP Negeri

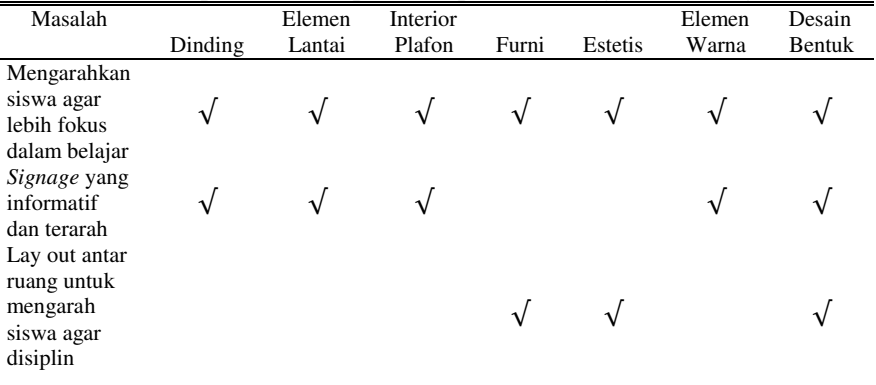

penanganan dalam masalah kedisiplinan di sekolah berupa sanksi dan tindakan yang tegas dan keras. Maka diperlukan bentuk yang dapat menyeimbangkan sebuah desain interior sekolah [5]. Sehingga siswa tidak merasa terkekang, namun mereka merasa diarahkan dan diatur untuk disiplin dalam melakukan kegiatan belajar mengajar. Bentuk-bentuk tersebut akan dikombinasi dan diaplikasikan ke dalam lay out furnitur pada setiap ruang (Gambar 5).

\section{3) Konsep Lantai}

Siswa SMP Negeri memiliki rasa ingin tahu yang tinggi serta mudah terpengaruh oleh kondisi sekitar. Serta penghuni sekolah lainnya seperti guru dan karyawan memiliki sifat yang disiplin serta menyukai suasana tenang dan nyaman sehingga ruangan yang dinamis sesuai untuk diterapkan di interior sekolah ini. Oleh karena itu, konsep lantai pada setiap ruang tidak terlalu banyak jenisnya. Agar pengguna bisa lebih terarah untuk berperilaku disiplin di sekolah, maka lantai menggunakan material keramik dengan tekstur tidak licin dan disertai dengan pola lantai yang merupakan signage untuk mengarahkan siswa agar berperilaku disiplin ketika berada di sekolah [6] (Gambar 6).

\section{4) Konsep Dinding}

Sebuah bangunan sekolah negeri di Indonesia banyak yang menggunakan dinding dengan material batu bata pada bagian fasad depan (eksterior). Hal ini bertujuan untuk mendeskripsikan secara tidak langsung bahwa bangunan tersebut adalah bangunan formal milik pemerintahan. Pada area interior menggunakan dinding batu bata dengan dominasi finishing cat tembok warna tosca dengan aksentuasi. Serta penambahan signage sesuai kebutuhan anak SMP sekaligus dapat mengarahkan pengunjung dan semua pengguna sekolah (guru, siswa, karyawan) (Gambar 7). 


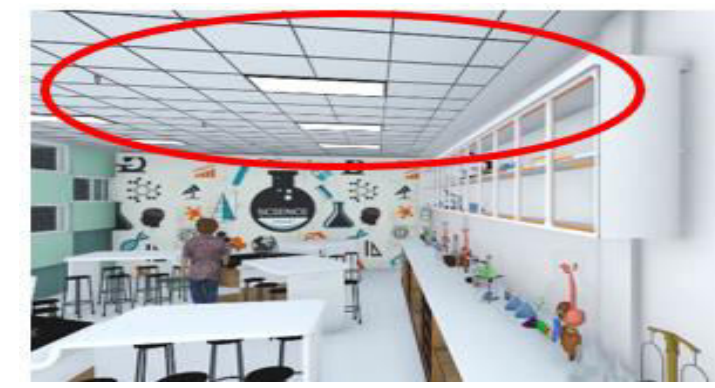

Gambar 8. Desain ceiling dengan material gipsum serta lampu TL pada interior sekolah.
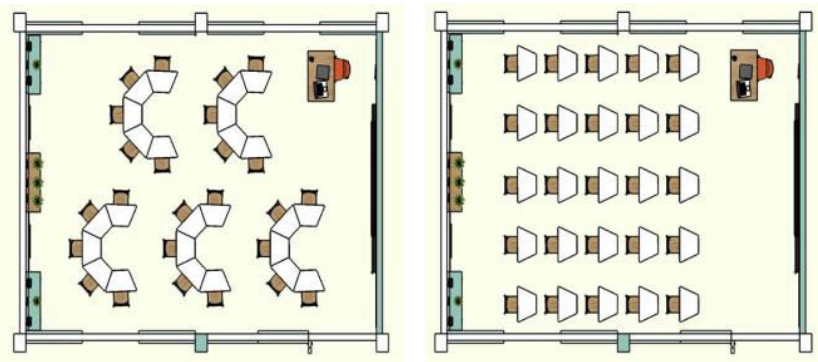

Gambar 9. Konfigurasi lay out furnitur pada Ruang kelas untuk interior SMP Negeri.

\section{5) Konsep Plafon}

Karena konsep dinding dan konsep lantai dibuat lebih dominan, maka sebagai penyeimbang agar ruangan terlihat lebih luas diaplikasikan material gipsum dengan aksen dropceiling/upceiling dan lampu dengan warna terang yang sesuai ketentuan pencahayaan untuk sekolah. Hal terpenting pada area belajar siswa adalah mengaplikasikan pencahayaan yang dapat menyebar keseluruh ruangan [5] (Gambar 8).

\section{6) Konsep Furnitur}

Furnitur menggunakan bentuk-bentuk geometris dengan material kayu jati belanda, multipleks dan struktur besi yang difinish dengan warna sesuai psikologis anak SMP. Storage didesain sesuai dengan kebutuhan siswa, guru, dan karyawan sekolah. Berikut ini salah satu contoh desain furnitur yang sesuai dengan kebutuhan siswa di ruang belajar (Gambar 9 dan 10).

Furnitur menggunakan bentuk yang dapat memberikan kesan tegas serta menggunakan warna yang memberikan kesan lembut dan tenang agar dapat meningkatkan kedisiplinan siswa namun tidak terlalu kaku. Sehingga siswa tidak merasa terkekang namun merasa untuk diarahkan bersikap lebih baik di sekolah. Pengaturan bangku mempunyai peranan penting dalam konsentrasi belajar siswa. Pengaturan bangku dapat dilakukan secara fleksibel dengan memosisikan sedemikian rupa, sesuai dengan kebutuhan pengajaran yang efektif dan efisien [7]. Hal ini dilakukan agar semua siswa mampu menangkap pelajran yang diberikan dengan merata, seksama, menarik, tidak monoton, dan mempunyai sudut pandang bervariasi terhadap pelajaran yang tengah diikuti.

7) Konsep Elemen Estetis

Elemen estetis pada desain interior sekolah ini mengaplikasikan elemen pembelajaran yang di transformasikan menjadi bentuk dan Gambar Menurut hasil observasi, siswa SMP Negeri lebih menyukai gambar atau simbol daripada tulisan. Maka elemen estetis diterapkan pada dinding dalam bentuk gambar dan simbol dari elemen belajar

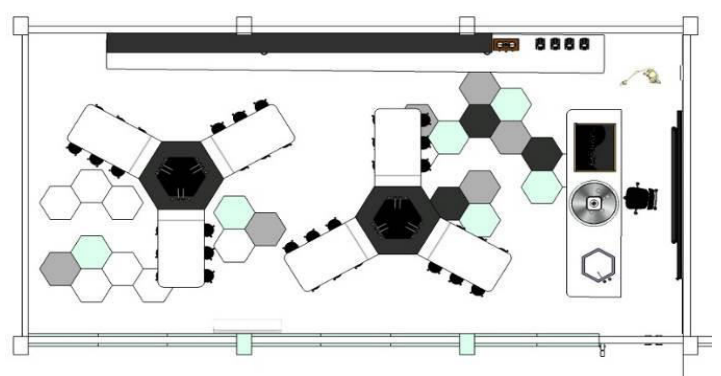

Gambar 10. Desain lay out furnitur pada laboratorium IPA.

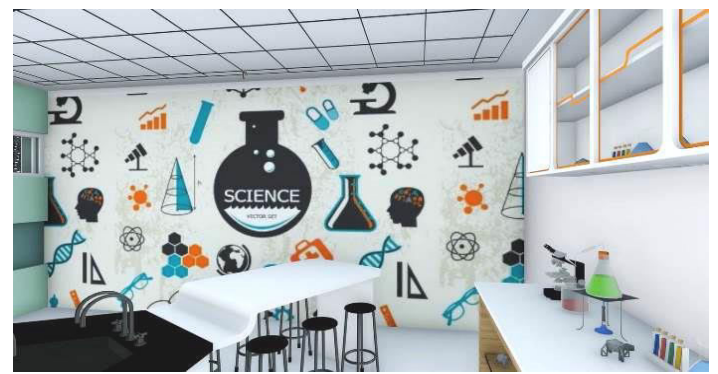

Gambar 11. Desain elemen estetis interior sekolah berupa mural dinding yang merupakan bentuk elemen belajar siswa.

seperti shempoa, globe, peralatan laboratorium, dan sebagainya. Penerapan elemen estetis pada interior harus tetap terarah agar lebih rapi dan bersih serta disesuaikan dengan siswa usia 12-15 tahun agar kegiatan belajar mengajar tidak membosankan dan dapat meningkatkan kedisiplinan siswa (Gambar 11).

\section{DESAIN AKHIR}

\section{A. Ruang Terpilih 1: Ruang Kelas}

Pada ruang kelas, lay out furnitur di desain secara berkelompok sesuai dengan sistem belajar yang ada di SMP Negeri saat ini. Aplikasi warna disesuaikan dengan psikologi siswa SMP dan terlihat pada semua elemen interior ruang kelas yang meliputi lantai, dinding, plafon, furnitur. Warna yang dipilih merupakan warna yang dapat membangkitkan daya konsentrasi dalam belajar serta membentuk sikap disiplin siswa (Gambar 12).

\section{B. Ruang Terpilih 2 : Kantin Sekolah}

Pada area kantin, desain signage pada lantai lebih dominan untuk mengarahkan siswa dan pengguna lainnya dalam melakukan aktivitas. Mulai dari masuk, mencuci tangan, mengambil baki/tempat makan yang bersih, antri mengambil makanan dan minuman, membayar di kasir, lalu siswa dapat keluar kantin atau makan di area makan yang telah disediakan. Kemudian siswa diarahkan untuk mengembalikan tempat makanan kotor dengan urutan membuang sampah, menaruh tempat makanan dan mencuci tangan. Pada umumnya SMP Negeri saat ini memiliki kantin yang belum terdesain dengan baik dan hal ini dapat menyebabkan perilaku siswa kurang disiplin. Kantin pada sekolah juga merupakan sarana pendidikan bagi siswanya. Karena di kantin, siswa dapat membiasakan dirinya berperilaku jujur, disiplin, sopan santun, dan cinta terhadap lingkungan sekitarnya (Gambar 13). 


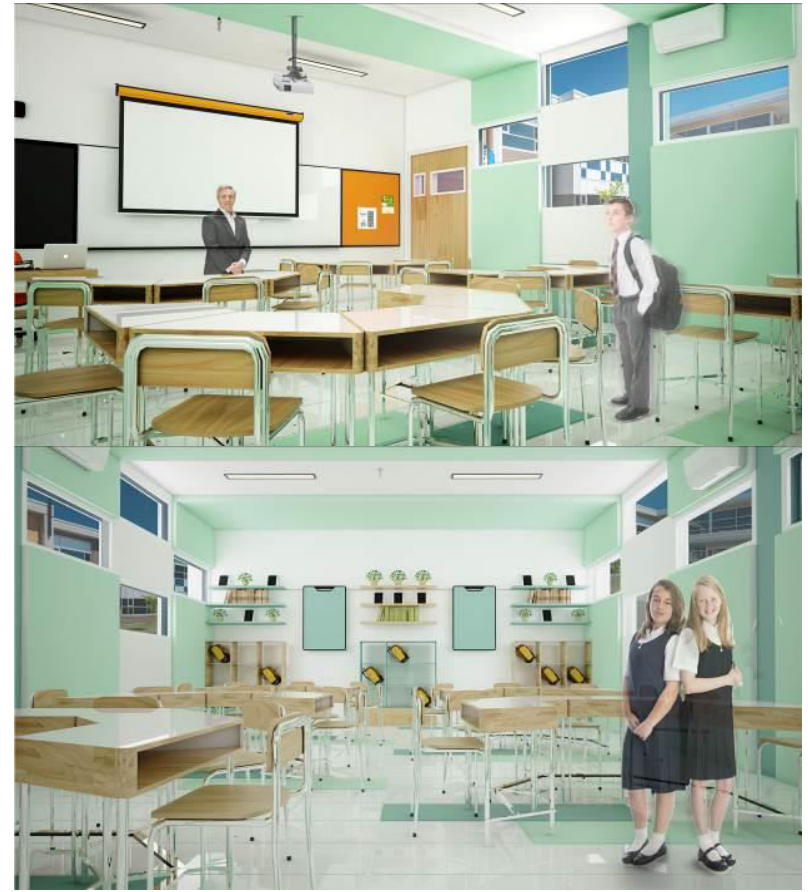

Gambar 12. Tampak View Ruang Kelas.

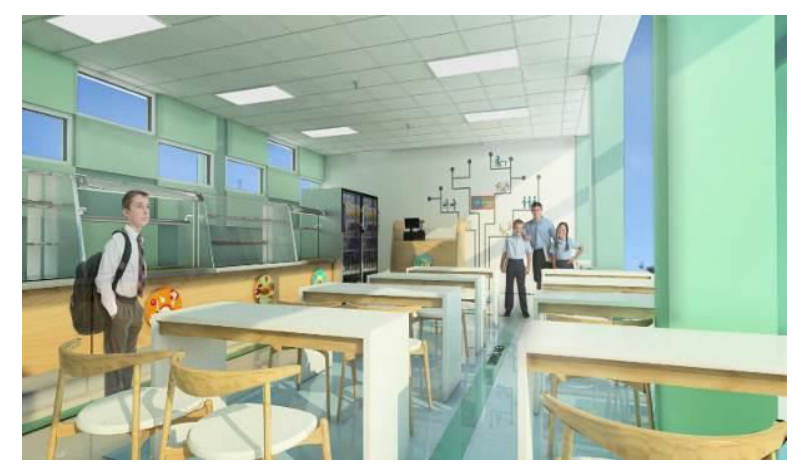

\section{Ruang Terpilih 3 : Laboratorium IPA}

Pada ruang laboratorium IPA, desain furnitur dan elemen estetis lebih dominan untuk mengarahkan siswa ketika sedang menjalanka tugas praktikumnya. Desain storage dan meja praktikum di desain secara berkelompok dan memiliki bentuk yang dinamis. Sehingga siswa merasa diarahkan untuk melakukan aktivitas seperti mengambil dan mengembalikan alat praktikum (Gambar 14).

\section{KESIMPULAN}

Desain lay out ruang dan sirkulasi pada ruangan yang ada di sekolah sangat penting bagi kelangsungan kegiatan belajar dan mengajar di sekolah. Yaitu sebagai tempat mencari ilmu, berinteraksi dengan orang lain, dan mengembangkan diri siswa. Lay out ruang dan sirkulasi ruang yang tepat adalah mengutamakan akses antar ruang sehingga aktifitas di sekolah dapat berjalan lebih optimal. Kemudian, pada dasarnya sebuah desain interior dapat mempengaruhi moody dan semangat pengguna sekolah yang meliputi siswa, guru, tamu, karyawan sekolah serta wali dari siswa. Desain yang memiliki unsur ketenagan akan membawa ke dalam tingkah laku yang positif

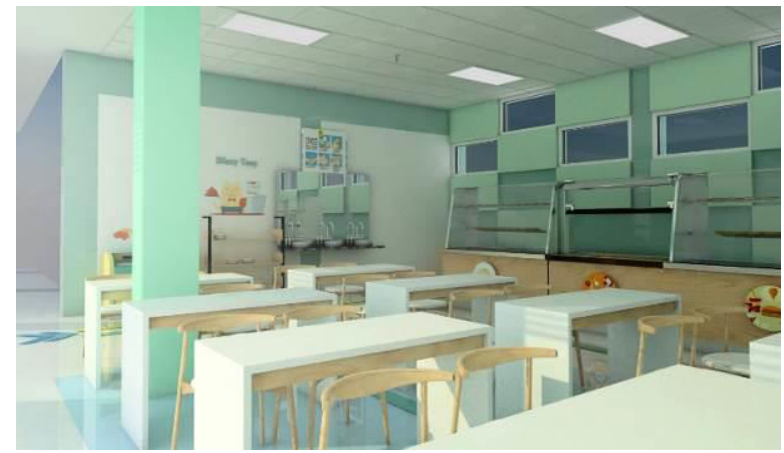

Gambar 13. Tampak View Kantin Sekolah.

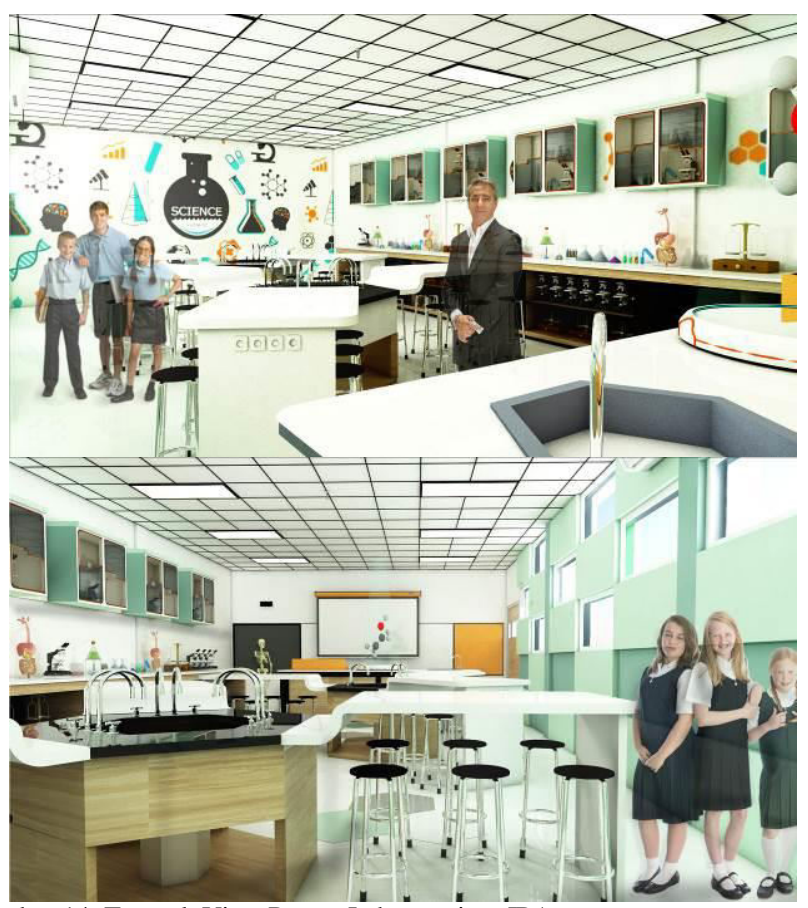

Gambar 14. Tampak View Ruang Laboratorium IPA.

dan baik. Seperti halnya warna dominan tosca, abu-abu dan aksentuasi hitam abu-abu, putih kecoklatan, coklat, kuning kecoklatan yang dapat membentuk sikap disiplin siswa. Dipastikan dengan warna-warna tersebut maka siswa dapat belajar dengan baik dan dapat meningkatkan prestasinya. Serta SMP Negeri dapat menciptakan suasana yang baru bagi siswa.

\section{DAFTAR PUSTAKA}

[1] A. Idi, Sosiologi Pendidikan (Individu, Masyarakat, dan Pendidikan). Jakarta: PT Raja Grafindo Persada, 2011.

[2] Desmita, Psikologi Perkembangan Peserta Didik. Bandung: PT Remaja Rosdakarya, 2009.

[3] A. Weny, "Studi Pengaruh Warna pada Interior Terhadap Psikologis Penggunanya, Studi Kasus pada Unit Transfusi Darah Kota X," $J$. Desain Inter., vol. 1, no. 1, 2016.

[4] J. Pile, Color in Interior Design. New York: Mc Graw Hill, 1997.

[5] F. Birren, New Horizons in Color. New York: Reinhold Publishing Corporation, 1955.

[6] M. Wardhana, "Logika Konfigurasi Ruang dan Aspek Psikologi Ruang bagi Lansia," J. Rekayasa Perenc., vol. 4, no. 1, 2007.

[7] M. Wardhana, "Spasial Analysis in Human Behaviour in The Environment to Predict Its Movement \& Comfort," in ISICO, 2015. 